\title{
MANIFESTATION OF PROSOCIAL AND ANTISOCIAL BEHAVIOUR IN A YOUTH GIRLS BASKETBALL MATCH
}

Saulius Šukys, Goda Mankutė

\author{
Lithuanian Academy of Physical Education, Kaunas, Lithuania
}

\begin{abstract}
Research background and hypothesis. Examining behavior in a youth girls basketball match it was hypothesized that players and coaches' behaviors would differ in relation with players' age, course and the final outcome of the match.

Research aim was to explore the manifestation of observed prosocial and antisocial behaviors in a youth girls basketball match.

Research methods. Fourty games were observed: 20 matches by U15 and 20 matches by U17 age groups.

Research results. Younger players more often argued with the referees $(\mathrm{p}=0.03)$, used physical aggression $(p=0.04)$. In the second half of the game players more often quarreled with referees $(p=0.05)$, welcomed unsuccessful actions of the rivals $(p=0.03)$. When the difference in the final result of the game was low, players more argued with the referees $(p=0.001)$ and used physical aggression $(p=0.01)$. Coaches working with younger players showed disrespect to them more often $(p=0.001)$. Such behaviours were more often at the beginning of the game $(p=0.001)$ and when the difference in the final result of the game was low $(p=0.04)$.

Discussion and conclusions. Research did not confirm that younger basketball players more often demonstrated respect to referee's decisions and opponents. Research confirmed that antisocial behaviors of players were more common in the second half of the match and when the difference in the final result was less. Research confirmed that coaches who worked with younger players demonstrated more antisocial behavior and that such behavior was more common when there was less difference in the results of the match.
\end{abstract}

Keywords: basketball players and coaches' behavior assessment, players' age, course of the game, final outcome of the game.

\section{INTRODUCTION}

$\mathrm{S}$ port represents one of the most important organized leisure activities for school aged children and adolescents (Rutten et al., 2008). As results show, almost one third of schoolchildren participate in sports activities (Silva et al., 2008; Tomik et al., 2012). Participation in organized youth sports yields specific experiences for children and provides them with new opportunities. Young athletes not only get opportunities to acquire specific skills and knowledge they need to perform their sports; they are also exposed to the moral values that are the foundation of sports-related rules and norms (Simon, 2000). It should be noted that in recent years the analysis of sports influence on adolescents' moral development has focused on athlete's prosocial and antisocial behaviours.

Prosocial behaviour has been defined as voluntary behaviour intended to help or benefit another individual while antisocial behaviour has been defined as voluntary behaviour intended to harmordisadvantage anotherindividual(Eisenberg, Fabes, 1998). Prosocial behaviour includes such acts as helping a player off the floor or congratulating a teammate for good play while antisocial behaviour includes acts like trying to injure an opponent or arguing with a teammate. It should be noted that in recent years a number of studies have been carried out to clarify the determinants of prosocial and 
antisocial behaviour. It has been established that task orientation and perceived mastery climate are positive predictors of prosocial behaviour, whereas ego orientation and perceived performance climate positively predicted antisocial behaviour (Kavussanu, 2006). Other studies suggest that moral disengagement has strong positive relationship with antisocial behaviour towards both teammates and opponents (Boardley, Kavussanu, 2009). It has also been established that coaching style, specifically autonomy-supportive coaching style is associated with prosocial behaviour of athletes (Hodge, Lonsdale, 2011). Some recent studies have found that prosocial attitudes in sport are predicted positively by moral and competence values, whereas antisocial attitudes are predicted positively by status and negatively by moral values (Lee et al., 2008). Research shows that adolescent athletes' prosocial behaviour is associated with sportspersonship attitudes and moral reasoning about sports dilemmas (Shields et al., 2007).

In summary we could conclude that most of these studies aim to analyze relationships between athletes' moral behaviour and contextual or personal factors. On the other hand, the focus is on athletes' actual behaviours in sports fights. However, there is a lack of studies directly recording and analyzing manifestations of athletes' behaviours. We can mention some studies dealing with aggression (Jones et al., 2005; VaezMousavi, Shojaei, 2005; Traclet et al., 2011) and prosocial as well as antisocial behaviours during competitions (Kavussanu et al., 2006; Kavussanu et al., 2009). Some studies mentioned above included both schoolchildren and adults (Kavussanu et al., 2009) or only boys (Kavussanu et al., 2006). Therefore, first of all this study aimed at clarifying basketball players' expression of prosocial and antisocial behaviours during the basketball game. As the coach leads the team in the course of the game during the match, the study analyzed the coach's behavior and its expression in the interface with the athletes' behaviours. Studying the behaviors of athletes during the match, we tested several hypotheses: (H1), younger female basketball players more frequently demonstrate respect for referees and contestants than the older ones, $(\mathrm{H} 2)$ antisocial behavior of basketball players is more common in the second half of the match, $(\mathrm{H} 3)$, the smaller the difference between the scores at the end of the match, the less respect for the opponent and the referees' decisions is noticed, and (H4) coaches training younger basketball players show more disrespect to players and referees during the match and such behavior is more characteristic when the match ends with a smaller difference.

\section{RESEARCH METHODS}

Basketball players' behaviours were measured through observational techniques. Based on the behaviour evaluation method employed in previous studies (Šukys et al., 2011) and preliminary observations of several basketball matches, a list of prosocial and antisocial behaviours was compiled. The evaluation of prosocial behaviours of basketball players allowed distinguishing the following forms: players' respect to referees (compliance with a foul, compatibility with other referee's decisions), respect to competitors (athletes' apologies after unauthorized actions against an opponent, help when they fall on the ground), and the etiquette of the game (such actions as greeting before and after the game, congratulating a teammate on making a successful shot or passing the ball). It should be noted that while distinguishing the last factor, the etiquette of the game, we referred to the studies by other researchers (Wells et al., 2008) who evaluated such actions e. g. the ones mentioned above as elements of game etiquette. Evaluating the antisocial behaviour of athletes we distinguished the following forms: disrespect to referees (noncompliance with a foul, objection to other referee's decisions), anger (being angry with teammates and competitors), conflicts using physical force (pushing teammates or opponents), physical aggression against an opponent, i. e. actions aiming at achieving certain goals but the outcome of which is usually a foul (e. g. the player bars the way, trips the opponent up, etc.), obscene vocabulary used by athletes, welcoming opponents' failures (clapping hands when opponent misses a free shot, releases the ball off the court, etc.) and players' quarrels (when arguing with opponents, team members, the coach). Antisocial behaviour of coaches was evaluated according to these groups of actions: disrespect for athletes (shouting at them, calling incorrect names), disrespect to referee's decisions (arguments with referees, commenting their decisions), obscene vocabulary of referees, and an extra group - coach's uncontrolled anger (hitting hand against the wall, trampling underfoot, throwing the table, etc.).

Although the reliability of observational data was assessed in the previous study (Šukys et al., 2011), after the adjustment of the observational protocol reliability was re-evaluated. In order to measure reliability of the data we estimated inter- 
observer reliability which was based on the scores of two observers who recorded the same information while simultaneously and independently observing the same individual or group behaviour (Sattler, Hoge, 2006). Although several procedures are available for measuring inter-observer reliability, we applied percentage agreement calculation. We carried out five control observations when the match was observed by two observers. Then we evaluated the percentage agreement of data recorded by both observers. As the observation took place directly during the match recording behaviours on the protocol, and not watching video-recorded materials, so we did not seek that the agreement was necessarily $100 \%$. No less than $86 \%$ agreement was detected evaluating each case of behaviour.

Research participants and procedure. The selected research participants were teams of schoolgirls participating in Lithuanian pupils' basketball league. It should be noted that the league included 97 teams of pupils of different age. We chose the age group of 13-17 years. They were divided into two age groups: U15 (age range 14-15 years) and U17 (age range 16-17 years). In the Basketball Tournament this age group was represented by 43 teams, 23 teams were involved in observation. We observed 40 matches: 20 matches by U15 age group (11 teams) and 20 by U17 age group (12 teams) accordingly. Observation took place in 2011. The organizers of the league were informed about the research, and their consent to observe the matches was received. The matches were observed in the cities of Kaunas, Vilnius and Šiauliai.

Statistical analysis. Analysis was conducted using statistical package SPSS for Windows 17.0. We registered the number of cases of behaviours during the whole research as well as the mean values per one game. Student's $t$ test was applied to verify the hypothesis about the differences in athletes and coaches' behaviours depending on basketball players' age and on the final result of the match. The differences in behaviours in the first and the second halves were assessed using Paired Samples $t$ test. Correlations between the variables of the research were estimated calculating Pearson's correlation coefficient. Statistical significance of differences was set at $\mathrm{p}<0.05$.

\section{RESEARCH RESULTS}

Our research revealed that during a match the mean frequency value of prosocial behaviours demonstrated by basketball players was 101.65
$(\mathrm{SD}=12.99)$ times, and the mean frequency value of antisocial behaviours - $71.85(\mathrm{SD}=19.49)$ times. The assessment of separate behaviours showed that on average basketball players showed respect to a referee $54.18(\mathrm{SD}=7.70)$ times a match, they demonstrated game etiquette $46.08(\mathrm{SD}=11.14)$ times and respect to their opponents only 1.4 $(\mathrm{SD}=1.71)$ times. The evaluation of antisocial behaviours revealed that during a game the basketball players contradicted to the referee 13.23 $(\mathrm{SD}=5.49)$ times on average, they got angry with other players $6.93(\mathrm{SD}=3.57)$ times, used physical aggression $37.50(\mathrm{SD}=7.94)$ times, used obscene words $3.90(\mathrm{SD}=2.47)$ times, welcomed rivals' failures $8.55(\mathrm{SD}=6.76)$ times and quarrelled 1.58 $(\mathrm{SD}=1.34)$ times per game. The coaches showed disrespect to athletes $39.35(\mathrm{SD}=12.15)$ times per game on average, they used obscene words 2.50 $(\mathrm{SD}=2.90)$ times and quarrelled with referees 2.85 $(\mathrm{SD}=2.29)$ times.

Our investigation did not reveal differences in the evaluation of prosocial behaviour demonstrated by different age basketball players during the match (Table 1). However, we observed that the younger basketball players demonstrated more antisocial behaviour during the match $(\mathrm{t}=2.04$, $\mathrm{p}<0.05)$. Accordingly, antisocial behaviour was more characteristic of their coaches during the match $(\mathrm{t}=3.49, \mathrm{p}<0.001)$. Observation revealed no behavioural differences in basketball players in the course of the match. However, statistically significant differences were established in the assessment of coaches' antisocial behaviour which often occurred in the first part of the match $(t=3.46$, $\mathrm{p}<0.001)$. Entering into detail of the data in Table 1 we see that players and coaches' behaviour differed most depending on the final result of the game.

Exploring the behaviour of players of different ages and their coaches during the match, it was found that younger players more often than the older ones argued with the referees during the match $(t=2.20, p<0.05)$, used physical aggression $(\mathrm{t}=2.17, \mathrm{p}<0.05)$ (Table 2). Coaches training younger basketball players also often showed disrespect for their trainees $(t=4.02 ; \mathrm{p}<0.001)$. According to the survey, basketball players more often disagreed with the referees in the second part of the game than at the beginning of the match $(\mathrm{t}=-2.06, \mathrm{p}<0.05)$, they more often welcomed unsuccessful actions of the rivals $(t=-2.33$, $p<0.05$ ). However, assessing the behaviour of the coaches it was established that they were more angry with their trainees in the first part of the game 
Table 1. Absolute and mean frequency values of basketball players and coaches' behaviours during the game in the aspect of the players' age, the course of the game and final result

\begin{tabular}{|c|c|c|c|c|c|c|}
\hline \multirow{3}{*}{ Research participants } & \multicolumn{6}{|c|}{ Basketball players and coaches' behaviour } \\
\hline & \multicolumn{2}{|c|}{$\begin{array}{c}\text { Prosocial behaviour of } \\
\text { basketball players }\end{array}$} & \multicolumn{2}{|c|}{$\begin{array}{c}\text { Antisocial behaviour of } \\
\text { basketball players }\end{array}$} & \multicolumn{2}{|c|}{$\begin{array}{c}\text { Antisocial behaviour of } \\
\text { basketball coaches }\end{array}$} \\
\hline & $\mathbf{N}$ & M (SD) & $\mathbf{N}$ & M (SD) & $\mathbf{N}$ & M (SD) \\
\hline $\begin{array}{l}\text { 14-15-year-old players } \\
16-17 \text {-year-old players }\end{array}$ & $\begin{array}{l}2111 \\
1955\end{array}$ & $\begin{array}{l}105.55(12.00) \\
97.75(13.05)\end{array}$ & $\begin{array}{l}1558 \\
1316\end{array}$ & $\begin{array}{l}77.90(22.33)^{* a} \\
65.80(14.29)\end{array}$ & $\begin{array}{c}1063 \\
752\end{array}$ & $\begin{array}{l}53.15(15.34) * * * a \\
37.60(12.75)\end{array}$ \\
\hline $\begin{array}{l}\text { First half of the games } \\
\text { Second half of the game }\end{array}$ & $\begin{array}{l}2029 \\
2037\end{array}$ & $\begin{array}{l}50.73(7.68) \\
50.93(7.82)\end{array}$ & $\begin{array}{l}1399 \\
1475\end{array}$ & $\begin{array}{l}34.98(10.57) \\
36.88(11.51)\end{array}$ & $\begin{array}{l}992 \\
823\end{array}$ & $\begin{array}{l}24.80(10.02)^{* * * b} \\
20.58(7.57)\end{array}$ \\
\hline $\begin{array}{l}\text { The final result differs in less } \\
\text { than } 10 \text { points }^{1}\end{array}$ & 1790 & $111.88(9.24) * * * \mathrm{c}$ & 1348 & $84.25(18.86) * * * \mathrm{c}$ & 827 & $51.69(15.28))^{* c}$ \\
\hline $\begin{array}{l}\text { The final result differs in } 10 \\
\text { points and more }\end{array}$ & 2276 & $94.83(10.46)$ & 1526 & $63.58(15.29)$ & 988 & $41.17(15.34)$ \\
\hline
\end{tabular}

Notes. Sixteen matches ended with a less difference than 10 points, and 24 matches - 10 points and more. The absolute values show the total number of registered actions in all matches observed. a - statistically significant difference comparing behaviours of players of different age and their coaches who trained them; $b$ - statistically significant difference comparing behaviours of players and their coaches in the first and second halves of the game; $\mathrm{c}-$ statistically significant difference comparing behaviours of players and their coaches during the game despite their final result. $*-\mathrm{p}<0.05 ; * * *-\mathrm{p}<0.001$.

$(\mathrm{t}=3.92, \mathrm{p}<0.001)$ and used obscene vocabulary $(t=2.80, p<0.01)$. Our observation revealed that when the difference in the final result of the game was low, athletes showed more behaviour linked to the etiquette of the game $(t=4.22, p<0.001)$, but they also more argued with the referees $(t=4.16$, $\mathrm{p}<0.001)$, welcomed unsuccessful actions of the rivals $(\mathrm{t}=4.24, \mathrm{p}<0.001)$ and used physical aggression $(\mathrm{t}=2.56, \mathrm{p}<0.01)$. Accordingly, the coaches also more often disagreed with the referees during the matches which ended in less than a 10 -point difference $(t=3.83, p<0.001)$. Moreover, in these matches coaches more often showed disrespect for their trainees $(t=2.09, \mathrm{p}<0.05)$.

The study also sought to determine the interrelationship between the coaches and basketball players' behaviour during the match. The findings showed that coaches' contradictions to referees correlated with such behaviours of players as quarrels with referees $(r=0.67$, $p<0.01)$, welcoming opponents' failures $(r=0.49$, $\mathrm{p}<0.01)$, physical aggression $(\mathrm{r}=0.50, \mathrm{p}<0.01)$ and quarrels with opponents $(\mathrm{r}=0.38, \mathrm{p}<0.01)$. Besides, we found a correlation between the use of obscene words of coaches and athletes during the game $(r=0.49, p<0.01)$. Accordingly, coaches' disrespect for athletes related to quarrels with referees $(\mathrm{r}=0.59, \mathrm{p}<0.01)$, physical aggression $(\mathrm{r}=0.59, \mathrm{p}<0.01)$ and the use of obscene words $(\mathrm{r}=0.38, \mathrm{p}<0.01)$. It should be noted that the coach's disrespect for trainees is associated with the coaches' disputes with referees $(r=0.53, p<0.01)$ and used obscenities $(r=0.63, p<0.01)$.

\section{DISCUSSION}

The study aimed at analysing the manifestation of basketball players' prosocial and antisocial behaviours during the game as well as establishing the manifestation of coaches' antisocial behaviour and its relations with athletes' behaviour. At the beginning of our research we expected younger basketball players to demonstrate respect to referees more often compared to the older ones, i. e. prosocial behaviour during the sports contest was more characteristic of them. This hypothesis was based in reference with previous research which found that antisocial behaviour in general and some forms of it (expression of aggression) were more typical of older athletes (Kavussanu et al., 2006; Papageorgiou et al., 2008; Šukys et al., 2011). Such tendencies were linked to athletes' experience which helped them circumvent the rules, put pressure on referees or imitate progress (Kavussanu et al., 2009). Besides, more experience is related to higher competition in achieving higher results, at the same time justifying seeking for victory at any cost (Conroy et al., 2001). However, our research did not confirm this hypothesis, i. e. prosocial behaviour was not characteristic of younger basketball players during the game, and some forms of antisocial behaviour, as objections to referees, physical aggression, were even more common. This could be explained by the lack of game experience. The less experience the basketball player has, the more often she commits a foul because she is not able to defend herself without breaking the rules. Similarly, the less 


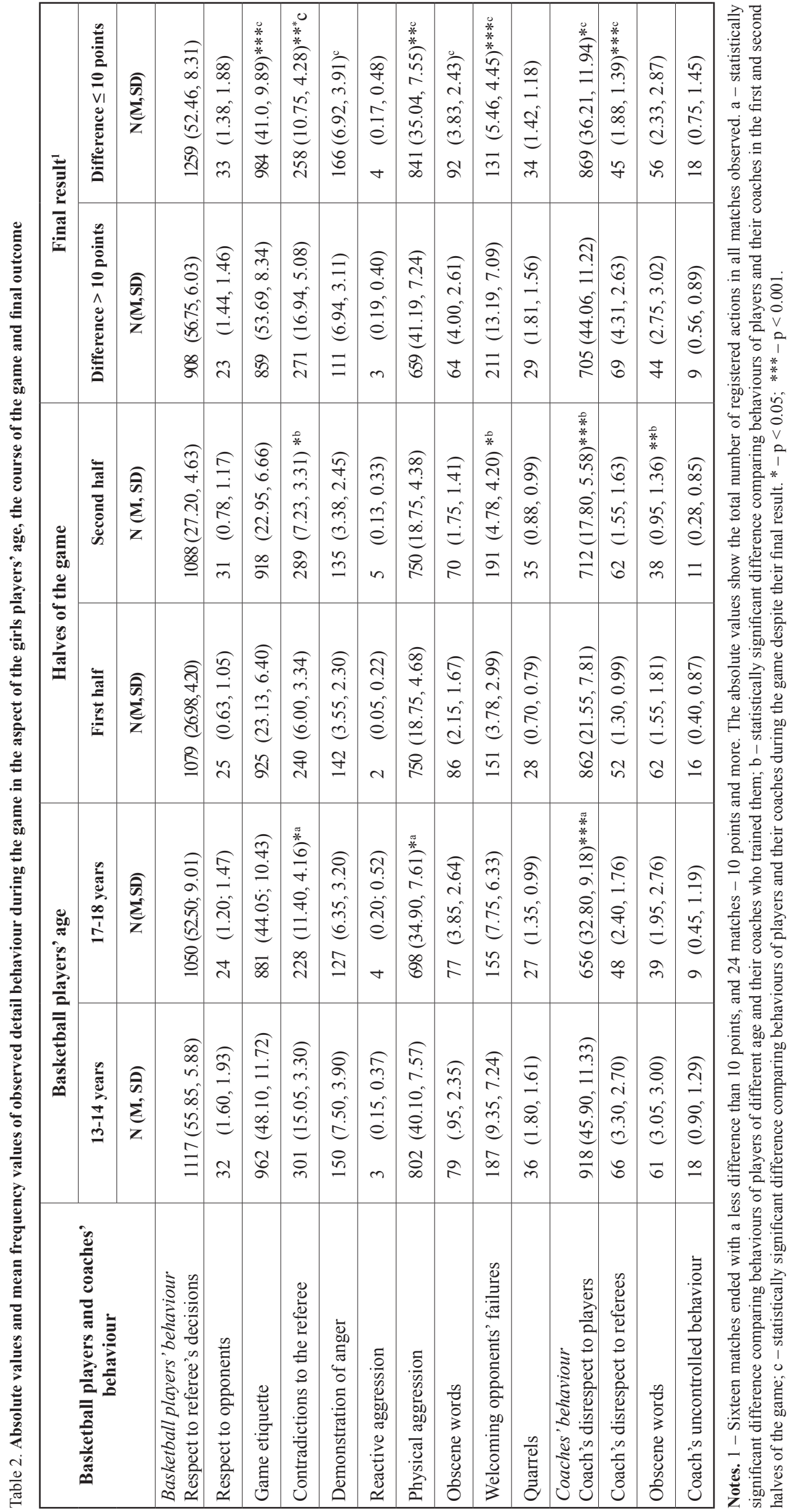


the player is experienced, the less she knows the rules of the game and the more often she makes mistakes, but she is unable to admit it and thus she contradicts to referees disagreeing with their decisions (denies making steps or breaking the rule of double dribbling the ball). This is in accord with the research data of T. M. Loughead and L. M. Leith (2001) claiming that younger icehockey players use instrumental aggression trying to compensate the lack of skills with it. It is worth noting that using curse words during the match among basketball players of different age does not differ, but in the similar research with boys it was established that older basketball players used curse words significantly more often during the game (Šukys et al., 2011).

It was also expected to find that antisocial behaviour of basketball players was more common in the second half of the game. This supposition was raised referring to the research data which show that in the second half of the match, the game becomes more aggressive (VaezMousavi, Shojaei, 2005), and the players more often contradict to referees (Šukys et al., 2011). It should be noted that the results of the observation of girls-basketball players revealed an analogous tendency confirming our supposition, i. e. in the second part of the game the girls more often argued with referees. On the other hand, it is very important to take the branch of sports into consideration while evaluating changes in the players' behaviour in the course of the game. For example, studying the evolution of rugby players' expression of aggression during the match, no differences were established (Jones et al., 2005).

The analysis of the data of basketball players' behaviours depending on the final score of the match was expected to reveal that the smaller the difference in the score at the end of the match, the less respect is given to opponents and the referee's decisions. It was established that when the game ended in less than a 10 point score difference, cases of antisocial behaviour of basketball players became more often, including contradictions to referees, physical aggression during fouls, welcoming opponents' failures. These data are not surprising because more even results highlight the aggressive fight which is sensitive to any action on the court, for example, aggressive actions of opponents can encourage returning like for like (Conroy et al., 2001). However, we can find research data testifying that winning teams also use much aggression, sometimes even more than losing teams (VaezMousavi, Shojaei, 2005). This is explained by athletes' attempt to keep control of the game and not to lose the match. Although, as it was mentioned above, the persistent fight when the result is equal can be associated with a higher tension, but the overall stress/strain is not necessarily related to athletes' aggressive behaviour (Ciairano et al., 2007).

The study also analysed the coach's behaviour during the match. Observation revealed that the hypothesis raised at the beginning of the research was confirmed, i.e. couches training younger basketball players more often demonstrate disrespect to them. It should be noted that this hypothesis was raised on the basis of analogous research observing behaviours of basketball coaches working with boys (Šukys at al., 2011). Analysis of coaching behaviour during the match showed that in the first of the match the coach's dishonourable conduct is more often and it is linked to the disrespect for the players and the use of obscene words. Such behaviours of coaches can be related the tension prevailing at the beginning of the match, as well as disappointment with the players who make mistakes more often due to the thrill of the start.

The study also confirmed the hypothesis that in a more tensed match (when the difference in score is not high) coaches tended to lose temper in this way demonstrating disrespect to trainees. We suppose that such behaviour is influenced by their wish to win when the victory is so close. In such matches it might be difficult to control emotions. On the other hand, this kind of behaviour might be the strategy chosen by the coaches themselves, i.e. coaches argue with referees consciously trying to put pressure on them and incline their decisions for the sake of their teams. This supposition is partly confirmed by research claiming that elite women's ice hockey coaches taught and demonstrated aggressive techniques to their athletes to gain an advantage in competition (Bloom, Vanier, 2004).

The study also established the relationship between antisocial behaviour of coaches and athletes in the course of the game. The findings were not unexpected. As coaches play an important role in developing the moral climate in the team, they are expected to teach children to behave prosocially. However, research shows that coaches use strategies to reduce moral responsibility and legitimize dishonourable actions of the players saying that deception is part of the game, aggression is a response to the aggressive actions 
of competitors and so on (Romand, Pantaleon, 2007). Personal coaching behaviour also affects the behaviour of players. It has been found that coaches' aggressive verbal communication determines athletes' disgraceful behaviour (Martin et al., 2007) or encourages believing that sportsmanship is not a value (Arthur-Banning et al., 2009). In fact, in our study, the data obtained suggest that coach's antisocial behaviour is associated with antisocial behaviour of players regardless of athletes' gender. This assumption refers to the similar relationships between coaches and boys players' antisocial behaviour during the match established in the previous study (Šukys et al., 2011).

Our research not only revealed some tendencies of the girls basketball players and coaches' conduct during the match, but it also showed further research perspectives. It would be appropriate to evaluate players and coaches' behaviours separately for each team. This would provide the opportunity to analyse the expression of antisocial and prosocial behaviour of the winning and the losing team. Besides, while assessing the behaviour of coaches during the game, it would be appropriate to compare male and female coaches because they have different communication styles (Martin et al., 2007).

\section{CONCLUSIONS AND PERSPECTIVES}

Younger girl basketball players less frequently agree with the referees' decisions and more often show aggression competing with their opponents. In general, antisocial behaviour is typical of those matches ending in a lower difference in the score. More often the coach demonstrates disrespect to younger basketball players, and they argue with referees and use obscene words in the first half of the match. Coaches are often angrier with trainees and referees in the games that end in a lower difference in the score. The study revealed that the coach's disrespect for referees and athletes correlated with antisocial behaviour of players during the match.

\section{REFERENCES}

Arthur-Banning, S., Wells, M. S., Baker, B. L., Hegreness, R. (2009). Parents behaving badly? The relationship between the sportsmanship behaviors of adults and athletes in youth basketball games. Journal of Sport Behavior, 32 (1), 3-18.

Bloom, G. A., Vanier, J. L. (2004). Coaches' perceptions of aggression in elite women's ice hockey. In D. J. Pearsall, A. B. Ashare (Eds.), Safety in Ice Hockey (4th ed., pp. 12-25). West Conshohocken, PA: ASTM International.

Boardley, I. D., Kavussanu, M. (2009). The influence of social variables and moral disengagement on prosocial and antisocial behaviors in field hockey and netball. Journal of Sports Sciences, 27 (8), 843-854.

Ciairano, S., Gemelli, F., Malinengo, G. et al. (2007). Sport, stress, self-efficacy and aggression towards peers: Unraveling the role of the coach. Cognition, Brain, Behavior, 11 (1), 175-194.

Conroy, D. E., Silva, J. M., Newcomer, R. R., Walker, B. W., Johnson, M. S. (2001). Personal and participatory socializers of the perceived legitimacy of aggressive behavior in sport. Aggressive Behavior, 27, 405-418.

Eisenberg, N., Fabes, R. A. (1998). Prosocial development. In N. Eisenberg (Ed.), Handbook of Child Psychology. Vol. 3: Social, Emotional, and Personality Development (pp. 701-778). New York: Wiley.

Hodge, K., Lonsdale, Ch. (2011). Prosocial and antisocial behavior in sport: The role of coaching style, autonomous vs. controlled motivation, and moral disengagement. Journal of Sport \& Exercise Psychology, 33 (4), 527-547.
Jones, M., Bray, S., Olivier, S. (2005). Game location and aggression in rugby league. Journal of Sports Sciences, 23 (4), 387-393.

Kavussanu, M. (2006). Motivational predictors of prosocial and antisocial behavior in football. Journal of Sports Sciences, 24 (6), 575-588.

Kavussanu, M., Seal, A. R., Phillips, R. D. (2006). Observed prosocial and antisocial behaviors in male soccer teams: Age differences across adolescence and the role of motivational variables. Journal of Applied Sport Psychology, 18, 326-344.

Kavussanu, M., Stamp, R., Slade, G., Ring, Ch. (2009). Observed prosocial and antisocial behaviors in male and female soccer players. Journal of Applied Sport Psychology, 21 (1), S 62-76.

Lee, M. J., Whitehead, J., Ntoumanis, N., Hatzigeorgiadis, A. (2008). Relationships among values, achievement orientations, and attitudes in youth sport. Journal of Sport and Exercise Psychology, 30 (5), 588-610.

Loughead, T. M., Leith, L. M. (2001). Hockey coaches and players perceptions of aggression and the aggressive behaviour of players. Journal of Sport Behavior, 24 (4), 394-406.

Martin, M. M., Rocca, K. A., Cayanus, J. L., Weber, K. (2007). Relationship between Coaches' use of behavor alteration techniques and verbal aggression on athletes' motivation and affect. Journal of Sport Behavior, 32 (2), 227-241.

Papageorgiou, M., Hassandra, M., Hatzigeorgiadis, A. (2008). Fair play in physical education: Effects of sex, age and intrinsic motivation. Inquiries in Sport \& Physical Education, 6 (2), 162-168. 
Romand, P., Pantaléon, N. (2007). A qualitative study of rugby coaches' opinions about the display of moral character. The Sport Psychologist, 21, 58-77.

Rutten, E. A., Deković, M., Stams, G. J. J. et al. (2008). On- and off-field antisocial and prosocial behavior in adolescent soccer players: A multilevel study. Journal of Adolescence, 31 (3), 371-387.

Sattler, J. M., Hoge, R. D. (2006). Assessment of Children. Behavioral, Social, and Clinical Foundations (5th Ed.). San Diego: Jerome M. Sattler Publisher Inc.

Shields, D. L., LaVoi, N. M., Bredemeier, B. L., Power, F. C. (2007). Predictors of poor sportpersonship in youth sport: Personal attitudes and social influence. Journal of Sport and Exercise Psychology, 29 (6), 747-762.

Silva. A. 1., Mourão-Carvalhal, M. I., Koelho, E. M. R. T. C., Libório, M. F. R. A. (2008). The impact of physical activity and sports practice in some health related parameters in school age students from Vila Real. Fitness Performance Juornal, 7 (3), 151-157.

Simon, R. L. (2000). Internalism and internal values in sport. Journal of the Philosophy of Sport, 27, 1-16.
Šukys, S., Zakrasienè-Stankevičiūtè, V., Nickus, E., Šukienè, E. (2011). Manifestation of prosocial and antisocial behavior in a basketball match. Ugdymas, Küno kultūra. Sportas, 4 (83), 69-76.

Tomik, R., Olex-Zarychta, D., Mynarski, W. (2012). Social values of sport participation and their significance for youth attitudes towards physical education and sport. Studies in Physical Culture and Tourism, 19 (2), 99-104. Traclet, A., Romand, P., Moret, O., Kavussanu, M. (2011). Antisocial behavior in soccer: A qualitative study of moral disengagement. International Journal of Sport and Exercise Psychology, 9 (2), 143-155.

VaezMousavi, S. M., Shojaei, M. (2005). Frequencies of aggressive behaviors in win, lose, and tie situations. International Journal of Applied Sport Sciences, 17 (1), $42-50$.

Wells, M. S., Arthum-Banning, S. G., Palsley, K. P. et al. (2008). Good (youth) sports: Using benefits-based programming to increase sportsmanship. Journal of Park and Recreation Administration, 26 (1), 1-21.

\title{
PROSOCIALAUS IR ANTISOCIALAUS ELGESIO RAIŠKA MERGAIČIŲ KREPŠINIO RUNGTYNIŲ METU
}

\author{
Saulius Šukys, Goda Mankutė \\ Lietuvos kūno kultūros akademija, Kaunas, Lietuva
}

\section{SANTRAUKA}

Tyrimo pagrindimas ir hipoteze. Gilinantis i prosocialaus ir antisocialaus elgesio raišką krepšinio rungtyniu metu, kelta prielaida, kad krepšininkių ir trenerių elgesys skirsis priklausomai nuo žaidėjų amžiaus, rungtynių eigos bei galutinio rezultato.

Tikslas - išsiaiškinti prosocialaus ir antisocialaus elgesio raišką mergaičių krepšinio rungtynių metu.

Metodai. Tiriant buvo naudotas stebėjimo metodas. Stebėta 40 (23 komandos) U15 ir U17 amžiaus grupiu mergaičių rungtynių.

Rezultatai. Tyrimas parodè, kad jaunesnès krepšininkès dažniau prieštarauja teisėjų sprendimams $(\mathrm{p}<0,05)$, naudoja fizinę agresiją ( $\mathrm{p}<0,05)$. Antroje rungtynių dalyje krepšininkès dažniau ginčijasi su teisèjais nei rungtynių pradžioje $(\mathrm{p}<0,05)$, džiaugiasi nesėkmingais varžovių veiksmais $(\mathrm{p}<0,05)$. Nustatyta, kad ginčai su teisėjais $(\mathrm{p}<0,001)$, fizinè agresija $(\mathrm{p}<0,01)$ būdingesni tose rungtynėse, kurios baigiasi mažesniu skirtumu. Dažniau nepagarbą treneris demonstruoja jaunesnèms krepšininkėms $(\mathrm{p}<0,001)$, ir toks trenerių elgesys būdingesnis pirmoje rungtynių dalyje $(\mathrm{p}<0,001)$. Treneriai dažniau rodo nepagarbą savo auklètinèms $(\mathrm{p}<0,05)$ ir ginčijasi su teisèjais $(\mathrm{p}<0,001)$ tose rungtynèse, kurios baigiasi nedideliu taškų skirtumu.

Aptarimas ir išvados. Tyrimas nepatvirtino keltos hipotezès, kad jaunesnès krepšininkès dažniau demonstruoja pagarbą teisejjams ir varžovams nei vyresnès. Pasitvirtino keltos hipotezès, kad antroje rungtynių dalyje krepšininkės demonstruoja daugiau antisocialaus elgesio ir jų elgesys skiriasi priklausomai nuo rungtyniu galutinio rezultato. Tyrimas patvirtino keltą prielaida, kad jaunesnes krepšininkes treniruojantys treneriai demonstruoja daugiau nepagarbos žaidèjams bei teisèjams rungtynių metu, ir toks elgesys būdingesnis tose rungtynėse, kurios baigiasi mažesniu skirtumu.

Raktažodžiai: krepšininkių ir trenerio elgesio vertinimas, žaidejų amžius, rungtynių eiga, rungtynių galutinis rezultatas.

Gauta 2012 m. spalio $30 \mathrm{~d}$.

Received on October 30, 2012

Priimta 2012 m. gruodžio 5 d.

Accepted on December 5, 2012
Corresponding author Saulius Šukys

Lithuanian Academy of Physical Education

Sporto str. 6, LT-44221 Kaunas

Lithuania

Tel +370 37302638

E-mail s.sukys@lkka.lt 